\title{
PEMANFAATAN BIOFILTER UNTUK MENGURANGI PEMAKAIAN BAHAN KIMIA DALAM PROSES PENGOLAHAN AIR ESTUARY
}

\author{
I Ketut Gede Suryawan ${ }^{1 *}$, I Gede Mahardika ${ }^{2)}$, \\ I Wayan Budiarsa Suyasa ${ }^{3)}$ \\ ${ }^{1)}$ PDAM Tirta Mangutama Kabupaten Badung \\ ${ }^{2)}$ Fakultas Peternakan Universitas Udayana \\ ${ }^{3)}$ Fakultas MIPA Universitas Udayana \\ *Email: suryaone.ketutgede@gmail.com
}

\section{ABSTRACT \\ USE OF BIOFILTER FOR REDUCING OF CHEMICALS USED IN ESTUARY WATER PROCESSING}

The process to supply the drinking water will also be expensive due to the decreasing quality of water it self. Some chemical substances are needed in high quantity to produce healthy water from Badung River, such as chlorine and aluminum sulphat $\left(\mathrm{Al} \mathrm{SO}_{4}\right)$. This is because the polutants of water in Badung River is really high. To decrease the use of the amount of chemical subtances and to avoid the side effect of chlorine on water which is highly organic, so this research was done through the use of biofilter. This biofilter is like bee-hive which is made from plastic. This micro-organism would scatter the organic substance and ammonia. In this case, iron $(\mathrm{Fe})$ and Manganese $(\mathrm{Mn})$ would be oxydized by the air and water from the blower. On the next step, the measurement of the content in each organic substance, iron, manganese, nitrate, nitrite, ammonia was done on the streaming water and the water that was out from biofilter reactor. In every parameter, the sampel was taken periodically from 1 to 6 hours hydrolic-setting time. The testing of using aluminum sulphate and the needs of chlorine was done in every 1 to 6 hours hydrolic-setting time. The result of the research told us that for 6 hours hydrolic- setting time could decrease $38.78 \%$ the organic substance, iron ( Fe) $41.93 \%$, manganese (Mn) $55.32 \%$, ammonia $75.40 \%$, nitrite $55.32 \%$, but nitrate increased up to $53.85 \%$. The increase of nitrate is still tolerable based on the law of governor (Pergub) Bali No. 8 year 2007. The use of chemical substance, in this case aluminum sulphat could be decreased up to $10 \mathrm{ppm}$ and chlorine (gas) could also be decreased until $10 \mathrm{ppm}$.

Key words : Water quality, biofilter, hydrolic-setting time, chemical substance

\section{PENDAHULUAN}

Air merupakan kebutuhan yang sangat pokok bagi manusia, terutama untuk memasak dan minum. Masalahnya adalah dengan semakin buruknya kualitas air baku untuk air minum, maka biaya pengolahannya akan semakin mahal. Salah satu untuk menghidari atau mengurangi terbentuknya THMs dalam air minum yakni menghilangkan senyawa yang secara langsung atau tidak langsung dapat menimbulkan terbentuknya THMs, dengan cara melakukan pengolahan awal (pretreatment) secara proses biologis (biological proces). Salah satu alternatif yang dapat dilakukan adalah dengan menggunakan proses biologis dengan sistem biofilter tercelup menggunakan media plastik sarang tawon.

Tujuan dari penelitian ini adalah Menentukan tingkat kemampuan biofilter sarang tawon dalam menurunkan kandungan terhadap parameter organik, amonia, nitrit, nitrat, besi, dan mangan. Mengetahui efektivitas biofilter dalam pengurangan pemakaian bahan kimia alumunium sulfat dan gas chlor khususnya pada free chlor pada instalasi pengolahan air Estuary.

Manfaat penelitian ini diharapkan dapat memberikan kontribusi dalam pembendaharaan tulisan ilmiah bagi dunia akademik lingkungan khususnya di bagian analisa kualitas air dan pengolahan air. Penelitian ini dapat memberikan dampak efesiensi biaya dalam pengolahan air dengan menghasilkan kualitas air yang memenuhi standar sesuai Peraturan Menteri Kesehatan Nomor 492/ Menkes/Per/IV/2010 tentang Persyaratan Kualitas Air Minum. Memberikan rekomendasi perbaikan kinerja untuk instlasi pengolahan air minum di daerah tercemar limbah organik. 


\section{METODOLOGI}

\subsection{Rancangan Penelitian}

Variasi debit air baku dilakukan untuk mendapatkan hubungan antara waktu tinggal hidrolis (WTH) terhadap penurunan konsentrasi zat organik. Waktu tinggal yang digunakan dalam penelitian ini adalah 6, 5, 4, 3, 2 dan 1 jam. Selama penelitian dilakukan pengambilan sampel untuk dilakukan analisa terhadap parameter zat organik , amonia, nitrat, nitrit, besi, mangan.

\subsection{Lokasi dan Waktu Penelitian}

Tempat penelitian dilakukan di ruang pompa intake IPA Estuary dan analisa parameter air dan uji pengolahan dilakukan di laboratorium IPA Estuary PDAM Tirta Mangutama Kabupaten Badung yang terletak di desa Suwung sekitar $5 \mathrm{~km}$ dari kota Denpasar, propinsi Bali. Posisi Instalasi Pengolahan berada pada $115^{\circ} 11^{\prime} 01,85^{\prime \prime}$ Bujur Timur dan 08 $43^{\prime} 41,96^{\prime \prime}$ Lintang Selatan. Elevasi dari muka laut $3 \mathrm{~m}$. Waktu penelitian dilakukan sekitar bulan Oktober 2014 sampai dengan Pebruari 2015.

\subsection{Ruang Lingkup Penelitian}

Pemeriksaan kualitas air dilakukan untuk mengetahui parameter-parameter yang terkandung dalam air. Pemeriksaan kualitas air yang dilakukan dilapangan seperti pengukuran temperature air dilakukan dengan thermometer elektronik, pengukuran $\mathrm{pH}$ dilakukan dengan alat $\mathrm{pH}$ meter.

Pemeriksaan kualitas air yang dilakukan di laboratorium seperti parameter kimia merupakan parameter-parameter yang relatif stabil atau dapat diawetkan. Pengukuran parameter kimia dilakukan dengan alat spectrophoto meter dan dilaksanakan di laboratorium induk PDAM Tirta Mangutama Kabupaten Badung.

Untuk menentukan dosis optimum bahan kimia dalam pengolahan air dilakukan di laboratorium dengan analisa uji pengolahan dan analisa break point chlorination.

\subsection{Peralatan Penelitian}

Peralatan (instrument) yang digunakan sebagai sarana pendukung yang penting dalam penelitian ini adalah :

1. Media biofilter yang dipergunakan adalah media biofilter sarang tawon media plastik yang terbuat dari PVC dengan spesifikasi :

- Luas permukaan $225 \mathrm{~m} 2 / \mathrm{m} 3$.

- $\quad$ Persentase rongga kosong $>90 \%$

- Ringan, mudah diletakkan di dalam tangki biologis.

2. Reaktor yang terbuat dari plat stainles sebagai tempat dari pada biofilter sarang tawon. reaktor dilengkapi dengan instalasi perpipaan baik untuk instalasi in let air baku, instalsi pipa out let, instalasi pipa udara untuk aerasi, dan pipa penguras. Reactor berukuran $190 \mathrm{~cm}$ x $120 \mathrm{~cm}$ $\mathrm{x} 50 \mathrm{~cm}$.

3. Blower sebagai sumber udara yang akan dihembuskan ke dalam reactor.

4. Peralatan jar tes untuk uji pengolahan di laboratorium

5. Peralatan untuk analisa air seperti Spectrophoto meter, pH meter, Conductivity meter dan peralatan untuk analisa BPC.
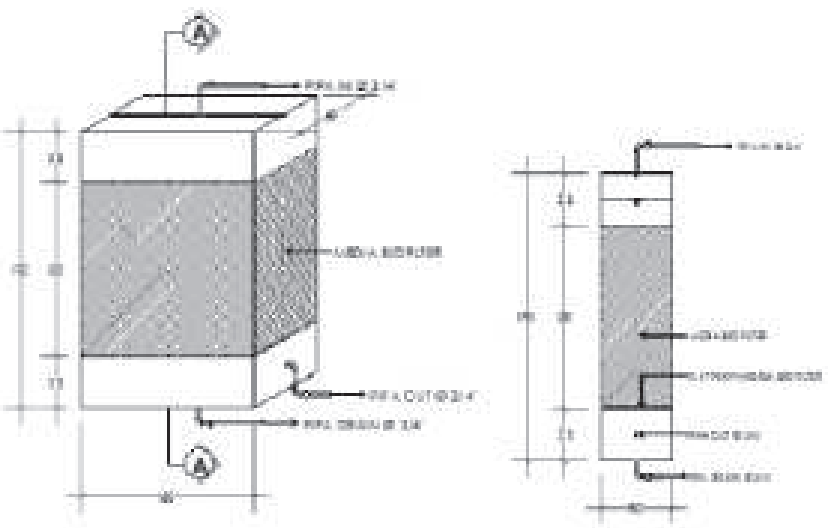

Gambar 1.

Reaktor Biofilter

\subsection{Analisis Data}

Dari perbandingan data air baku dengan out let biofilter akan diperoleh tingkat penurunan parameter zat organik, amonium, nitrat, nitrit, besi dan mangan. Pembandingan hasil pengolahan dilakukan untuk melihat efektifitas penggunaan biofilter untuk mengurangi pemakaian alumunium sulfat dan gas chlor. Akan dilakukan perbandingan pemakaian bahan kimia dalam hal ini penentuan dosis optimum dengan menggunakan alat jar tes dan break point chlorination tes.

Setelah tercapainya pertumbuhan biofilm maka akan dilakukan perubahan aliran untuk mendapatkan waktu tinggal 1, 2, 3, 4, 5 dan 6 jam. Dari perbandingan hasil tersebut akan diperoleh data waktu tinggal yang paling efektif dalam proses biofilter.

\section{HASIL DAN PEMBAHASAN}

Lapisan biofilm merupakan mikroorganisme yang dapat menguraikan zat pencemar organik yang terdapat dalam air. Setelah dua minggu lalu dilakukan pengukuran zat organik.

Dari hasil pengukuran nilai sat organik selama tiga minggu diperoleh rata-rata penurunan nilai sat organik $20,35 \%$. Polutan sat organik akan diuraikan oleh mikroorganisme dalam biofilter dan waktu tinggal hidrolis akan mempengaruhi tingkat penurunan polutan dalam air. 

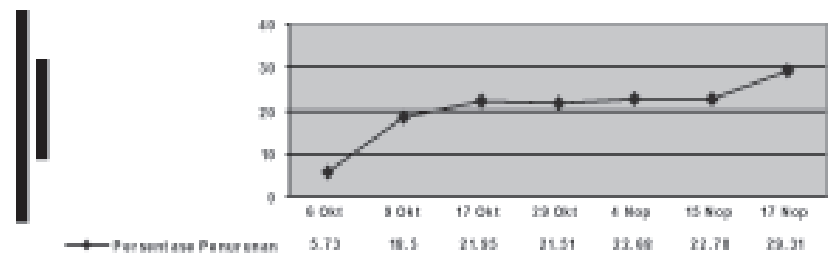

Gambar 2.

Persentase Penurunan Zat Organik Pada Tahap Pertumbuhan Mikroorganisme

\subsection{Penurunan Zat Organik}

Air baku yang mengandung zat organik akan melalui biofilter yang sudah di tumbuhi lapisan lendir sehingga terjadi proses biologis. Efesiensi biofilter tergantung dari luas bidang kontak atau lamanya waktu tinggal hidrolis seperti pada gambar 3.

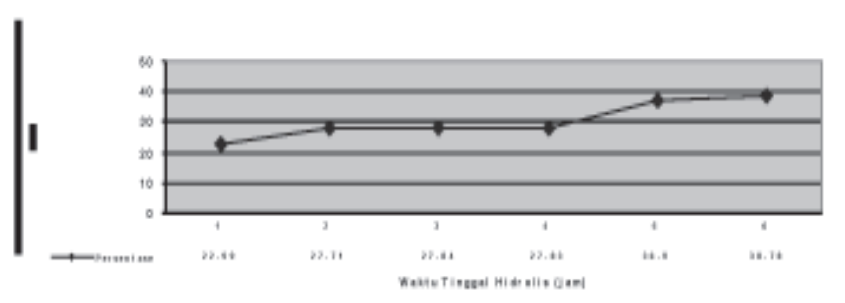

Gambar 3.2

Persentase Penurunan Zat OrganikAkibat Waktu Tinggal Hidrolis

Hasil penelitian menunjukkan bahwa ketika waktu tinggal diubah menjadi empat jam efisiensi penghilangan zat organik sekitar 27,83\%.Dari hasil tersebut diketahui bahwa semakin pendek waktu tinggal hidrolis yaitu dari 6 jam menjadi 1 jam, maka efisiensi penghilangan zat organik $\left(\mathrm{KMnO}_{4}\right)$ pada kondisi stabil juga menjadi semakin kecil yakni dari $38.78 \%$ menjadi $22.99 \%$.

\subsection{Penurunan Zat Mangan}

Waktu tinggal hidrolis sangat mempengaruhi besarnya prosentase penurunan kadar mangan. Hal ini terjadi air yang berada lebih lama dalam biofilter mendapatkan oksidasi dan waktu mengendap yang lebih lama.Persentase penurunan dapat dilihat dalam gambar 4.

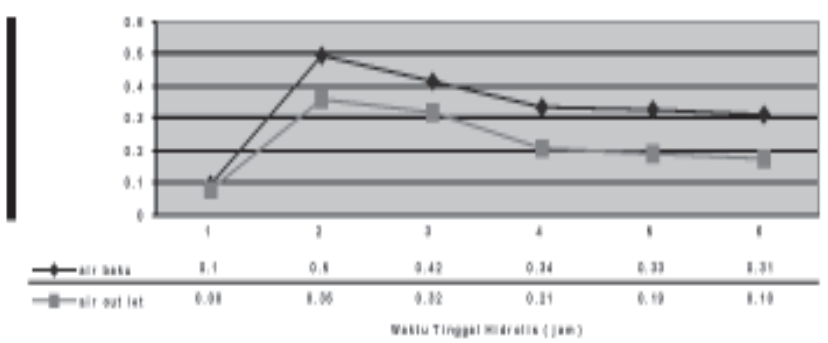

Gambar 4.

Kandungan Mangan Dalam Air Baku dan Air Out Let.

Kandungan mangan rata-rata pada air out let sebesar 0,22 mg/l masih diatas baku mutu air kelas
I sebesar 0,1 mg/l sesuai dengan Peraturan Gubernur Bali no.16 tahun 2016. Kadar mangan mengalami penurunan antara air baku dengan air out let karena adanya sistem aerasi yang dapat mengoksidasi mangan sehingga dapat diendapkan.

\subsection{Penurunan Zat Besi}

Dalam proses pengolahan air garam besi valensi dua yang larut dalam air harus dirubah menjadi garam besi valensi tiga yang tak larut dalam air sehingga mudah untuk diendapkan. Dalam reaktor biofilter terdapat proses aerasi dengan blower yang berfungsi sebagai oksidator dan sebagai penambahan oksigen untuk pertumbuhan mikroorganisme. Hasil oksidasi besi dalam reaktor dapat kita lihat dalam gambar 5 .

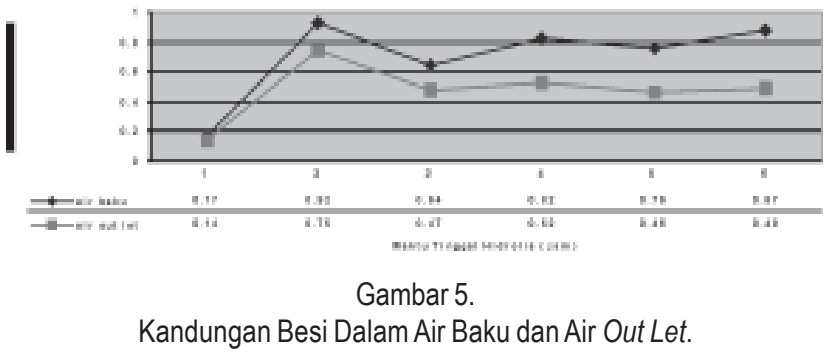

Biofilm mampu menurunkan 23,33\% untuk waktu tinggal hidrolis 1 jam dan 41,93\% untuk waktu tinggal hidrolis 6 jam. Untuk rata-rata kandungan zat besi pada air out let sebesar $0,47 \mathrm{mg} /$ l sehingga masih diatas $0,3 \mathrm{mg} / \mathrm{l}$ baku mutu air kelas I sebagai air untuk air baku air minum sesuai Peraturan Gubernur Bali Nomor 16 tahun 2016. Penurunan kadar besi lebih disebabkan adanya sistem aerasi dalam biofilter sehingga terjadi proses oksidasi besi. Zat besi dalam air membentuk ferro $(\mathrm{Fe} 2+)$ yang tidak berwarna dan akan berubah menjadi feri ( $\mathrm{Fe} 3+)$ berupa endapan.

\subsection{Penurunan Zat Nitrit}

Kandungan nitrit dalam air bersifat sangat labil yang sangat dipengaruhi oleh kandungan oksigen. Besarnya penurunan kandungan nitrit dalam air baku dengan waktu tinggal hidrolis seperti gambar 6 .

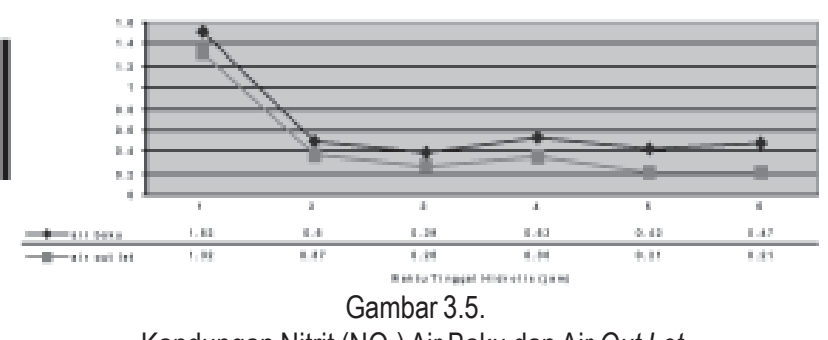

Kandungan Nitrit $\left(\mathrm{NO}_{2}\right)$ Air Baku dan Air Out Let.

Kadar nitrogen dalam air baku berkisar 0,42 mg/ $1-1,52 \mathrm{mg} / \mathrm{l}$, dalam air out let mengalami penurunan menjadi berkisar $0,21 \mathrm{mg} / \mathrm{l}-1,32 \mathrm{mg} / \mathrm{l}$. Untuk waktu tinggal 1 jam terjadi penurunan sebesar $13,6 \%$ untuk 6 jam terjadi penurunan sebesar $55,32 \%$. 


\subsection{Penurunan Zat Nitrat}

Keberadaan senyawa nitrat dalam perairan pada umumnya dipakai sebagai parameter untuk mengukur tingkat kesuburan perairan. Perubahan kandungan nitrat dalam air baku dengan waktu tinggal hidrolis seperti pada gambar 7 .

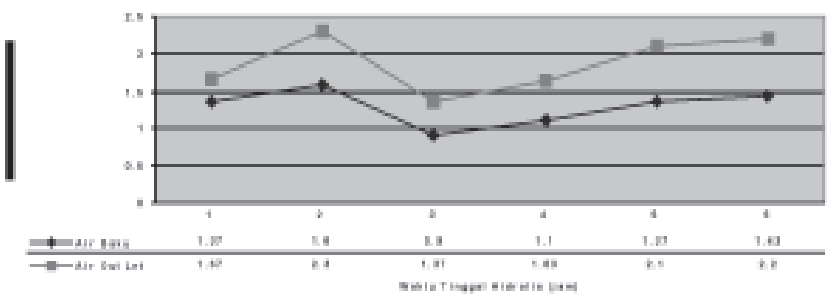

Gambar 7.

Kandungan Nitrat $\left(\mathrm{NO}_{3}\right)$ Air Baku dan Air Out Let

Konsentrasi nitrat cenderung meningkat pada air olahan dibandingkan dengan air bakunya , karena reaksi nitrifikasi menghasilkan nitrat. Konsentrasi nitrat dalam air baku berkisar $0,9 \mathrm{mg} / \mathrm{l} \mathrm{sd} \mathrm{1,6} \mathrm{mg/l,}$ sedangkan dalam air olahan meningkat menjadi 1,37 $\mathrm{mg} / \mathrm{l} \mathrm{sd} 2,3 \mathrm{mg} / \mathrm{l}$.

\subsection{Penurunan Zat Amonium}

Sumber terbesar amonia dalam perairan adalah limbah nitrogen organik seperti urea dan protein serta nitrogen anorganik yang terdapat dalam tanah yang berasal dari dekomposisi bahan organik seperti tumbuhan dan hewan yang telah mati. Jika kandungan oksigen cukup tinggi maka amonia akan mengalami konversi menjadi nitrat atau nitrifikasi. Perubahan kandungan amonia air baku dengan waktu tinggal hidrolis seperti pada gambar 8 .

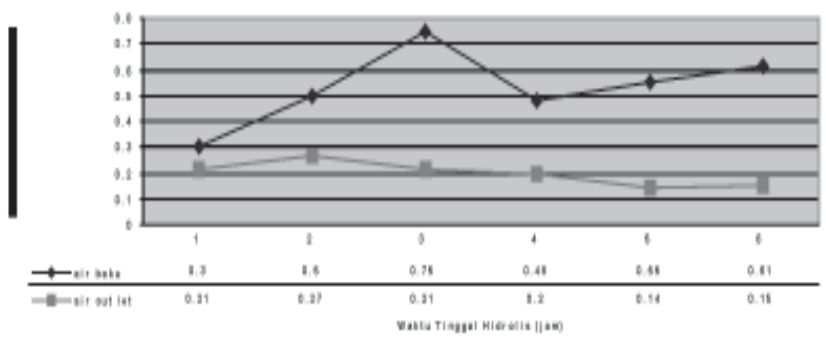

Gambar 8.

Kandungan Amonia Dalam Air Baku dan Air Out Let

Dari uraian diatas terjadi peningkatan persentase penurunan kadar amonia dari waktu tinggal hidrolis 1 jam sebesar 43,21\% dan untuk waktu tinggal hidrolis 6 jam 75,40\%. Nilai ratarata amonium air out let sebesar $0,20 \mathrm{mg} / \mathrm{l}$ masih di bawah standar baku mutu air kelas I sebesar 0,5 mg/l sesuai dengan Peraturan Gubernur Bali No.16 tahun 2016.

\subsection{Penurunan Mikrobiologi}

E.coli merupakan salah satu bakteri coliform total. Keberadaan coli tinja menggambarkan tingkat pencemaran perairan oleh kotoran manusia. Kandungan E.coli dalam air baku dapat diturunkan dengan biofilter seperti gambar 9 .
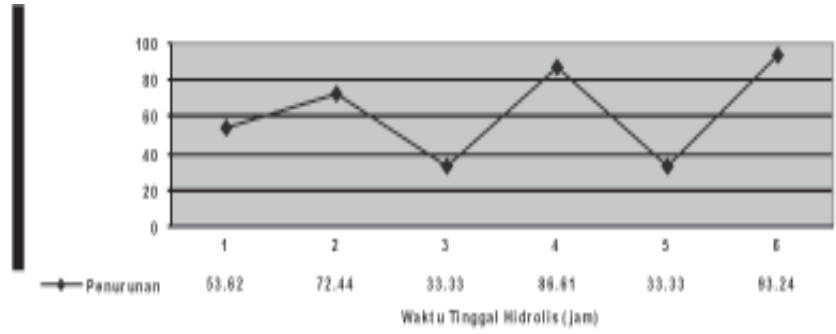

Gambar 9.

Persentase Penurunan E.coli Dengan Waktu Tinggal Hidrolis

E.coli enterotoxigenic dapat menyebabkan radang lambung dan diare yang hebat disertai dengan kram perut dan muntah-muntah (Harris, 1986). Air dan makanan merupakan faktor penularan atau penyebaran dari E.coli tersebut.

\subsection{Efesiensi Pemakaian Bahan Kimia Khlor}

Dalam proses pengolahan air, khlor berfungsi sebagai desinfeksi dan oksidator. Jumlah sisa khlor sebagai standar pada sistem penyediaan air bersih adalah $0.5-1,0 \mathrm{mg} / \mathrm{l}$. Sisa khlor dipakai sebagai ukuran jumlah khlor yang masih ada dalam air yang akan dapat memaparkan bila terjadi pencemaran dalam air tersebut. Semakin besar teroksidasinya amonia dan semakin besar berkurangnya khlor. Persentase penurunan khlor akibat penggunaan biofilter dengan berbagai waktu tinggal hidrolis seperti tabel 1.

Dengan menggunakan biofilter sarang tawon dengan waktu tinggal hidrolis 1 jam dapat mengurangi pemakaian khlor sebesar 4,6 ppm atau $26,3 \%$ dan untuk 6 jam sebesar 6 ppm atau $66,7 \%$.

\subsection{Efesiensi Pemakaian Bahan Kimia Alumunium Sulfat}

Koagulan yang digunakan adalah alumunium sulfat $\mathrm{Al}_{2}\left(\mathrm{SO}_{4}\right)_{3} \cdot 18 \mathrm{H}_{2} \mathrm{O}$. alumunium sulfat mengikat partikel koloid, zat organik, zat anorganik, sehingga terbentuk gumpalan flok yang akan dapat dengan cepat dan mudah mengendap. Efesiensi pemakaian alumunium sulfat dapat dilihat dengan membandingkan hasil uji pengolahan atau jar tes antara air baku dengan air out let. Hasil perbandingan dapat dilihat pada Table 2.

Hasil uji pengolahan atau jar tes untuk air baku mendapatkan dosis optimum pemakaian alumunium sulfat sebesar 90 ppm sedangkan untuk air out let 80 ppm. Jadi dari perbandingan hasil uji pengolahan penggunaan biofilter sarang tawon dengan waktu tinggal hidrolis satu jam sampai dengan enam jam dapat mengurangi pemakaian alumunium sulfat sebesar $11,1 \%$ s/d $16,7 \%$. 
Tabel 1. Persentase Penurunan Penggunaan Khlor Pada Berbagai Waktu Tinggal Hidrolis

\begin{tabular}{cccccc}
\hline No & WTHJam & In Letmg/ltr & Out Letmg/ltr & Selisihmg/ltr & Prosentase penurunan \\
\hline 1 & 1 & 19 & 14 & 5 & 26,3 \\
2 & 2 & 13 & 8 & 5 & 38,5 \\
3 & 3 & 8 & 3 & 6 & 62,5 \\
4 & 4 & 11 & 5 & 6 & 54,5 \\
5 & 5 & 12 & 6 & 6 & 50,0 \\
6 & 6 & 9 & 3 & 6 & 66,7 \\
\hline
\end{tabular}

Tabel 2. Pengurangan Pemakaian Alumunium Sulfat

\begin{tabular}{lcccc}
\hline No & WTHJam & In Letmg/tr & Out Letmg/ltr & Selisihmg/tr \\
\hline 1 & 1 & 90 & 80 & 10 \\
2 & 2 & 80 & 70 & 10 \\
3 & 3 & 90 & 80 & 10 \\
4 & 4 & 60 & 50 & 10 \\
5 & 5 & 70 & 60 & 10 \\
6 & 6 & 60 & 50 & 10 \\
\hline
\end{tabular}

\section{SIMPULAN DAN SARAN}

\subsection{Simpulan}

Berdasarkan hasil penelitian dan pembahasan diatas dapat disimpulkan beberapa hal sebagai berikut :

1. Pemanfaatan biofilter dapat menurunkan kandungan zat organik sebesar $38,78 \%$, besi $41,93 \%$, mangan $43,68 \%$, nitrit $55,32 \%$, amonium $75,40 \%$ dalam air baku waduk muara.

2. Tingkat efektifitas biofilter mengurangi pemakaian khlor sebesar $26,3 \%$ untuk waktu tinggal hidrolis 1 jam dan $66,7 \%$ untuk waktu tinggal hidrolis 6 jam dan alumunium sulfat sebesar $11,1 \%$ untuk waktu tinggal hidrolis 1 jam dan 16,7\% untuk waktu tinggal hidrolis 6 jam.

\subsection{Saran}

1. Untuk tercapainya efektifitas dalam pemakaian khlor dalam proses pengolahan air waduk muara yang menggunakan biofilter harus menggunakan waktu tinggal hidrolis minimal 3 jam.

2. Dilakukan perubahan aliran dari atas menjadi ke atas sehingga menambah kesempatan untuk terjadinya endapan yang akan dapat mengurangi jumlah sat padat tidak terlarut (Total suspendid solid) sehingga bisa menambah efektifitas pemakaian alumunium sulfat.

3. Pada proses pengolahan air dengan air baku mengandung limbah domestik yang pada prosesnya memakai free chlor bisa menggunakan biofilter sebagai pengolahan tahap awal sehingga dapat mengurangi pemakaian bahan kimia khlor.

\section{DAFTAR PUSTAKA}

Adisanjaya N.Ngr, Budiarsa Suyasa I W, Sundra K. 2011.Analisis Efektifitas Proses Pengolahan Limbah PT. Indonesia Power Unit Bisnis Pembangkit (UPB) Bali Berbasis Microsoft Visual Foxpro. Ecotropihic 6 (2):139-145.

Alaert, G dan Sri Sumestri Santika. 1984. Metoda Penelitian Air. Usaha Nasional. Surabaya.

Bennet,S. 1997. Ground Water Contamination From Leaking Home Heating Oil System. Country Kildare. Ireland.

Boyd, C.E. 1988. Water Quality in Warmwater Fish Ponds. Fourth Printing. Auburn University Agricultural Experiment Station, Alabama, USA. 359p.

Cole, G.A. 1988. Textbook of Limnology. Third edition. Waveland Press, Inc., Illionis, USA. 401p.

Dharma Putra, Ketut Gede. 2009. Petunjuk Teknis Pemantauan Kualitas Air. Udayana University Press. Denpasar.

Departemen Pekerjaan Umum. 2007. Laporan Akhir Pengkajian Teknologi Pengolahan Air Waduk Muara di Nusa Dua. Badan Penelitian dan Pengembangan Pekerjaan Umum Pusat Penelitian dan Pengembangan Sumber Daya Air Balai Lingkungan Keairan. Bandung

Grady, C.P.L and Lim, H.C. 1980. Biological Wastewater Treatment. Marcel Dekker Inc. New York. 
Gubernur Bali. 2016. Peraturan Gubernur Bali No 16 Tahun 2016 tentang Baku Mutu Lingkungan Hidup dan Kriteria Baku Kerusakan Lingkungan Hidup. Denpasar.

Hefni Effendi. 2003.Telaah Kualitas Air Bagi Pengelola Sumber Daya dan Lingkungan Perairan. Kanisius. Yogyakarta.

Indra Wahyuni, Ni Made. 2014.Efektivitas Sistem Biofilter Aerob Dalam Menurunkan Kadar Amonia Pada Air Limbah. Tesis. Universitas Udayana. Bali.

Kodoati, Rebert J. dan Sjarief, Roestam. 2010. Tata Ruang Air. Andi. Yogyakarta.

Menteri Kesehatan. 2010. Peraturan Menteri Kesehatan Nomor 492/Menkes/Per/IV/2010 tentang Persyaratan Kualitas Air Minum. Jakarta.
Metcalf and Edy. 1987. Waste Water Engineering. Mc Graw Hill.

Nusa Idaman Said. 1999. Kesehatan Masyarakat dan Teknologi Peningkatan Kualitas Air. Direktorat Teknologi Lingkungan Deputi Bidang Teknologi Informasi, Energi, Material dan Lingkungan Badan Pengkajian dan Penerapan Teknologi. Jakarta.

Rukaesih Achmad. 2004. Kimia Lingkungan. Andi. Yogyakarta.

Seksi Laboratorium. 2002. SOP Pemeriksaan Kualitas Air. Perusahaan Daerah Air Minum Kabupaten Badung. Denpasar.

Waluyo, Lud. 2009. Mikrobiologi Lingkungan. UMM Press. Malang 